\author{
${ }^{[0000-0002-8380-3102]}$ А. В. Громико, к.m.н., \\ доиент кафедри хімічних технологій та водоочищення ЧДТУ, \\ e-mail: gromyko-andru@ukr.net \\ ${ }^{[0000-0001-5287-3733]}$ Г. С. Столяренко, д.m.н., професор, \\ завідувач кафедри хімічних технологій та водоочищення ЧДТУ, \\ М. В. Позігун, студент \\ e-mail: lemax_95@ukr.net \\ Черкаський державний технологічний університет \\ б-р Шевченка, 460, м. Черкаси, 18000, Україна
}

\title{
ВИКОРИСТАННЯ ПРИРОДНИХ СОРБЕНТІВ В ПРОЦЕСАХ ОЧИЩЕННЯ ПОГЛИНАЛЬНИХ РОЗЧИНІВ ПОТАШУ ВИРОБНИЦТВ АМІАКУ
}

На кафедрі хімічних технологій та водоочищення Черкаського державного технологічного університету було проведено експериментальні дослідження з визначення адсорбиійної здатності активованих бентонітових глин щодо поглинання із розчинів поташу смолистих речовин та корозійно активних сполук. У ході роботи встановлено, що бентонітові глини, активовані методом кислотної та лужсної активації, мають достатню поглинальну здатність щодо смолистих речовин та корозійно активних сполук, щоб провести заміну активованого вугілля, щңо використовується для циих цілей на виробництві.

Виявлено, щзо найнижчим ступенем поглинання иільових компонентів розчину поташу характеризується глина кислотної активаиії. Глина лужної активаиії також поглинає в проиесі адсорбиії $\mathrm{K}_{2} \mathrm{CO}_{3}, \mathrm{KHCO}_{3}$, ДЕА та $\mathrm{V}_{2} \mathrm{O}_{5}$, але більшою мірою, ніж глина кислотної активації. Найбільший ступінь поглинання має активоване вугілля. Цей недолік активованого вугілля викликає необхідність постійного поповнення поглинального розчину новими пориіями $\mathrm{K}_{2} \mathrm{CO}_{3}$, $\mathrm{KHCO}_{3}$, ДЕА, ще збільшує виробничі витрати на очищення синтез-газу від оксиду вуглещю (IV).

Ключові слова: виробництво аміаку, розчини поташу, корозія, очищення, адсорбиія, активована глина.

Вступ. На сьогодні на підприємствах хімічної промисловості з виробництва аміаку у схемі синтезу, на стадії конверсії оксиду вуглецю, дуже гостро стоїть проблема очищення розчинів моноетаноламіну (MEA) і поташних розчинів, активованих диетаноламіном (ДЕА), які застосовуються для очищення газів від диоксиду вуглецю. Тривала експлуатація таких розчинів (розчин типу «Карсол» (25-28\% $\mathrm{KHCO}_{3}$ та 1,8\% диетаноламіну) та розчин типу «Бенфілд» (29-30\% $\mathrm{KHCO}_{3}$ та 2,9 \% диетаноламіну)) призводить до зниження їх поглинальної здатності. На стадії високотемпературної регенерації в об'ємі розчинів проходять побічні процеси термічного розкладання диетаноламіну, в результаті чого утворюються смолисті речовини та корозійно активні з'єднання, для видалення яких у технологічну схему вводять додаткову стадію фільтрації розчинів на вугільних фільтрах.

На виробництвах аміаку для очищення газу від $\mathrm{CO}_{2}$ застосовують розчини етаноламінів (аміноспиртів), які мають лужні властивос- ті і при взаємодії з кислотами утворюють солі [1]. Зазвичай використовують водні розчини моноетаноламіну $\mathrm{CH}_{2} \mathrm{OH}-\mathrm{CH}_{2}-\mathrm{NH}_{2}$, діетаноламіну $\left(\mathrm{CH}_{2} \mathrm{OH}-\mathrm{CH}_{2}\right) \quad 2 \mathrm{NH}$ i триетаноламіну $\left(\mathrm{CH}_{2} \mathrm{OH}-\mathrm{CH}_{2}\right) 3 \mathrm{~N}$. Найбільш сильною основою серед етаноламінів $\epsilon$ моноетаноламін, який знайшов широке застосування в промисловості для очищення газів.

Поглинальна здатність абсорбенту зростає зі зниженням температури і підвищенням тиску. При підвищенні температури і зниженні тиску рівновага хімічних реакцій, що проходять при абсорбції, зсувається вліво. На цьому грунтується регенерація розчинів етаноламінів, насичених кислими газами при абсорбції. Насичений розчин нагрівають, при цьому відбувається розкладання хімічних сполук і десорбція кислих газів 3 розчину, супроводжувана також випаровуванням з розчину води. В процесі етаноламінового очищення газу від $\mathrm{CO}_{2}$ проходять також побічні реакції, що викликають незворотні зміни складу розчину, які знижують його поглинальну здатність і призво- 
дять до втрат аміну. Розчини етаноламінів викликають корозійне руйнування обладнання в певних умовах, особливо при високих ступенях насичення кислими газами.

За останній час процес моноетаноламінового очищення фізично і морально застарів. Актуальним стало завдання створення нового абсорбенту, який характеризується меншою деградацією і корозійною активністю розчину, а також вимагає менших енерговитрат для його декарбонізації [2].

Одним із поширених методів вирішення цих завдань у світовій практиці є заміна моноетаноламіну (MEA) на метилдіетаноламін (МДЕА). Відомо, що реакційна здатність азотовмісних груп у первинних алканоламінах, таких як MEA, вища, ніж у вторинних алканоламінах, таких як діетаноламін (ДЕА), і третинних алканоламінах, таких як триетаноламін (ТЕА) і метилдіетаноламін (МДЕА). Наявність третьої ОН-групи в молекулі ТЕА послаблює реакційну здатність азотовмісних груп, тому МДЕА має дещо вищу поглинальну здатність, ніж ТЕА.

Розчини МДЕА легше регенеруються, швидкість корозії і деградації розчину менша, ніж у МЕА. 3 другого боку, кінетика абсорбції $\mathrm{CO}_{2}$ розчинами МДЕА не забезпечує необхідний ступінь очищення синтез-газу. Цей недолік компенсують добавкою різних активаторів, найчастіше вторинних і первинних алканоламінів [3].

МДЕА (третинний амін) порівняно 3 MEA (первинний амін) має меншу корозійну активність, що дає змогу застосовувати на стадії абсорбції більш концентровані водні розчини МДЕА (30-50\% мас.) порівняно 3 MEA (12-18\%).

Нині значного поширення набуло очищення газу від $\mathrm{CO}_{2}$ гарячими розчинами карбонатів, активованими різними добавками.

Методи очищення газів гарячим розчином поташу [4] базуються, насамперед, на зростанні розчинності солей у воді при збільшенні температури, тому для очищення можуть бути використані більш концентровані розчини. Оскільки розчинність солей калію у воді вища розчинності солей натрію, для абсорбції застосовують розчини поташу.

Важливою перевагою процесу абсорбції при високих температурах є значне збільшення швидкості гідратації двоокису вуглецю i, отже, швидкості абсорбції в цілому. Ці фізико-хімічні особливості дали можливість здійс- нити такий процес очищення, в якому абсорбція і регенерація проходять майже при однакових температурах, причому абсорбція проходить при підвищеному тиску, а регенерація - при тиску, близькому до атмосферного.

Теплота розчинення $\mathrm{CO}_{2}$ в поташних розчинах приблизно в 2,5 разу менша теплоти розчинення у водному розчині моноетаноламіну і дорівнює $6,04 \cdot 10^{2}$ кДж/кг $\mathrm{CO}_{2}$. Оскільки теплота розчинення визначає швидкість зниження розчинності газу при збільшенні температури, то розчинність $\mathrm{CO}_{2}$ в розчинах $\mathrm{K}_{2} \mathrm{CO}_{3}$ в цих умовах змінюється повільніше розчинності в моноетаноламіні. Наприклад, при тиску 0,71 МПа і підвищенні температури від $65,6{ }^{\circ} \mathrm{C}$ до $132,2{ }^{\circ} \mathrm{C}$ розчинність двоокису вуглецю в $30 \%$-му розчині $\mathrm{K}_{2} \mathrm{CO}_{3}$ зменшується лише в 1,6 разу. Таке зниження розчинності $\mathrm{CO}_{2}$ компенсується збільшенням концентрації $\mathrm{K}_{2} \mathrm{CO}_{3}$ [5].

Автори відзначають ряд позитивних особливостей процесу очищення газу від $\mathrm{CO}_{2}$ гарячим розчином поташу, що дають змогу істотно знизити витрати тепла на виробництві. При моноетаноламіновому очищенні приблизно 40-60 \% тепла витрачається на підігрів розчину внаслідок недорекупераціі в теплообмінниках. При очищенні гарячим розчином поташу ця стаття витрат значною мірою (при грубому очищенні - повністю) відпадає.

Крім того, при моноетаноламіновому очищенні 25-30 \% тепла витрачається на розкладання сполук моноетаноламіну 3 двоокисом вуглецю. При поташевому очищенні, як зазначено вище, ця величина зменшується в 2,5 разу, тому пар витрачається в основному лише на віддування $\mathrm{CO}_{2}$ в десорбері, а також на покриття теплових втрат в навколишнє середовище.

Крім економії пари, очищення гарячим розчином поташу має й інші переваги. Процеси абсорбційного очищення зазвичай пов'язані 3 необхідністю охолодження конвертованого газу, який в подальшому знову повинен нагріватися (наприклад при подальшому метануванні), тому в разі очищення поташним розчином зменшується витрата води на охолодження конвертованого газу, а також частково відпадають ii витрати на охолодження розчинника. Крім того, знижуються витрати на абсорбент (порівняно з моноетаноламіновим очищенням). Капітальні витрати знижуються головним чином за рахунок зменшення поверхні теплообмінної апаратури. 
Процес гарячого поташевого очищення має також серйозні недоліки. Основний 3 них - сильна корозія обладнання. Як інгібітор корозії застосовують біхромат калію, який додається у кількості 3 г/л. При наявності в газі сірководню витрати інгібітора значно зростають внаслідок взаємодії з ним. Таким чином, незважаючи на принципову можливість одночасного очищення газу від сірководню двоокису вуглецю, практично процес застосовний тільки для відмивання $\mathrm{CO}_{2}$. Великі труднощі викликає також ерозія обладнання (особливо насосів) при пересичені розчину внаслідок випадання солей заліза та ін. Для боротьби 3 ерозією розчин фільтрують, а засувки промивають конденсатом, приєднуючи його потім до розчину.

На деяких виробництвах як поглинальні розчини використовують гарячі розчини поташу, активовані діетаноламіном (ДЕА). До таких розчинів відносяться «Бенфілд», «Карсол». У розчині «Карсол» абсорбентом є 25$28 \%$-й розчин поташу, вміст ДЕА в ньому становить близько $1,8 \%$. Крім того, в розчин додають інгібітор корозії - оксид ванадію (V) $(0,4 \%)$ і антиспінювач (різні силіконові масла). Розчин «Бенфілд» відрізняється від розчину «Карсол» в основному більшою концентрацією $\mathrm{K}_{2} \mathrm{CO}_{3}$ i ДЕА. Перевагою розчинів «Карсол» і «Бенфілд» $є$ відносно низькі витрати тепла (близько 5,45 МДж/м ${ }^{3} \mathrm{CO}_{2}$ ) без урахування тепла гарячого конвертованого газу, що надходить в абсорбер, а також малі витрати на теплообмінні поверхні внаслідок близькості температур абсорбції і регенерації.

Розчинність $\mathrm{CO}_{2}$ в поташ-діетаноламінових розчинах, а також тиск парів води над цими розчинами вивчені при температурі від $60{ }^{\circ} \mathrm{C}$ до $120{ }^{\circ} \mathrm{C}$, тиску до $0,811 \mathrm{MПа,} \mathrm{концент-}$ раціях $\mathrm{K}_{2} \mathrm{CO}_{3}$ від $20 \%$ до $30 \%$ і ДЕА від $1,5 \%$ до $10 \%$ [5].

Авторами було досліджено вплив концентрації $\mathrm{K}_{2} \mathrm{CO}_{3}$ на поглинальну здатність розчину при $100{ }^{\circ} \mathrm{C}$ і концентрації ДЕА, що дорівнює $5 \%$ (0,5 моль/л). Результати дослідження показали, що розчинність $\mathrm{CO}_{2}$ (в моль/моль $\mathrm{K}_{2} \mathrm{CO}_{3}+$ ДЕА) дещо зменшується при збільшенні концентрації $\mathrm{K}_{2} \mathrm{CO}_{3}$ [6].

Дослідження швидкості абсорбції $\mathrm{CO}_{2}$ гарячими розчинами поташу 3 добавками ДЕА в апараті з мішалкою показало, що прискорююча дія ДЕА, як правило, є невеликою. Так, при вмісті близько $4 \%$ ДЕА коефіцієнт прискорення при малих ступенях карбонізації не перевищує 1,5. Однак він зростає до 2 при високих ступенях насичення (тобто в умовах низу абсорбера), коли абсолютне значення коефіцієнта масопередачі є малим. В умовах верху абсорбера, очевидно, головну роль відіграє зниження парціального тиску $\mathrm{CO}_{2}$ над розчином при додаванні ДЕА, тобто можливість більш тонкого очищення $[7,8]$.

Однак цей метод має ряд недоліків. Так, при порівнянні з процесом МЕА-ГИАП встановлено, що витрата тепла в удосконаленому процесі МЕА-очищення трохи нижча, ніж у розчині «Карсол», й істотно (майже удвічі) знижується циркуляція розчину.

Тривала експлуатація таких розчинів (розчин типу «Карсол» (25-28\% $\mathrm{KHCO}_{3}$ та 1,8 \% ДЕА) та розчин типу «Бенфілд» (29-30 \% $\mathrm{KHCO}_{3}$ та 2,9 \% ДЕА)) призводить до зниження їх поглинальної здатності. На стадії високотемпературної регенерації в об'ємі розчинів проходять побічні процеси термічного розкладання ДЕА, в результаті чого утворюються смолисті речовини та корозійно активні з'єднання, для видалення яких в технологічну схему вводять додаткову стадію фільтрації розчинів на вугільних фільтрах. Використання вугільних сорбентів потребує їх частої регенерації гострим паром та призводить до безповоротних втрат ДЕА і додаткових матеріальних затрат на заміну активованого вугілля. Заміна ж самих розчинів ускладнюється тим, що вони містять як інгібітор корозії таку токсичну речовину, як $\mathrm{V}_{2} \mathrm{O}_{5}$, що важко утилізується [9].

Деякі автори пропонують спростити технологію регенерації розчинів поташу «Карсол» і «Бенфілд» і знизити експлуатаційні та матеріальні витрати на очищення розчинів поташу від смолистих та корозійно активних речовин шляхом заміни в технологічній схемі вугільного адсорбера на мембранну установку, а як мембрани використати полімерні ацетатцелюлозні мембрани, що ущільнюються під тиском, типу МГА - мембрана гіперфільтраційна ацетатцелюлозна для зворотного осмосу або типу УАМ - ультрафільтраційна ацетатцелюлозна мембрана. Однак експлуатація ацетатцелюлозних мембран вимагає їх частої заміни або регенерації, оскільки пори забиваються високомолекулярними смолистими речовинами, що ускладнює експлуатацію обладнання технологічної схеми процесу очищення газу гарячим розчином $\mathrm{K}_{2} \mathrm{CO}_{3}$, активованим ДЕА, та підвищує затрати на ії обслуговування [10]. 
Метою роботи $\epsilon$ проведення досліджень процесів адсорбції активованими природними сорбентами, а саме монтморилонітом, смолистих та корозійно активних речовин 3 розчинів поташу, активованих диетаноламіном, і розробка рекомендацій по заміні активованого вугілля на стадії регенерації розчинів поташу на активовані природні сорбенти.

Матеріали та методи дослідження. Як об'єкт дослідження використовували поглинальні поташні розчини виробництва аміаку ПАТ «Азот» м. Черкаси 3 вмістом смолистих речовин у розчині 44,375 г/дм ${ }^{3}$ та мурашиної кислоти 0,018 г/дм ${ }^{3}$.
Як адсорбенти використовувались бентонітові глини в комбінації III+IV шар кислотної активації та II+IV шар лужної активації.

Вимірювання вмісту смолистих речовин у розчинах поташу проводилося оптичним методом 3 використанням однопроменевого спектрофотометра Ulab 1023 діапазоном довжин хвиль 325-1000 нм. Вимірювання масової концентрації карбонатів (бікарбонатів) калію, диетаноламіну, масової частки п'ятивалентного ванадію в розчині поташу проводилося методом титрування 3 використанням титратора автоматичного TitroLine ${ }^{\circledR} 5000$.

Дослідження проводилися в лабораторних умовах на установці, схему якої зображено на рисунку 1.

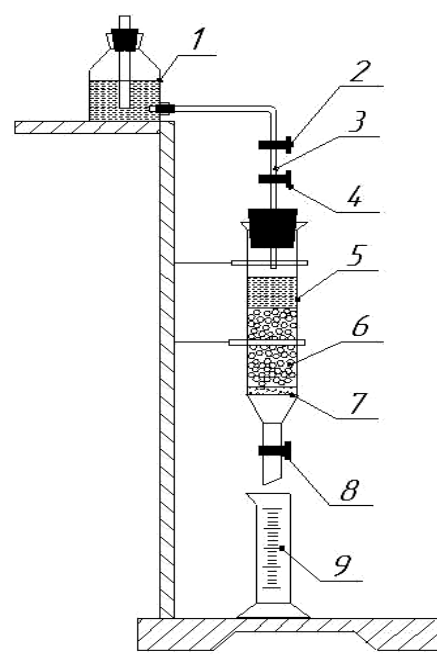

1 - склянка з розчином поташу; 2, 4 - запірний кран; 3 - з’єднувальна трубка;

5 - адсорбційна колонка; 6 - активована глина; 7 - пориста скляна пластинка; 8 - нижній кран; 9 - мірний циліндр

Рисунок 1 - Лабораторна адсорбційна установка

Установка складається 3 ємкості для подачі розчину поташу об'ємом 5 дм $^{3}(1)$, запірних кранів $(2,4)$, які призначені для регулювання кількості розчину, що подається в адсорбційну колонку (5). Колонка завантажена активованою глиною (6). Для регулювання швидкості пропускання розчину поташу через адсорбційну колонку в іiї нижній частині поставлено кран (8). Мірний циліндр (9) призначено для визначення кількості очищеного розчину поташу, що пройшов через адсорбційну колонку.

Результати та їх обговорення. Першим етапом досліджень було перевірити адсорбційну здатність активованих глин щодо поглинання із розчинів поташу смолистих речовин та мурашиної кислоти, що утворю- ються в їх об’ємі під час високотемпературної регенерації.

В адсорбційну колонку насипали глину, що пройшла відповідну активацію, та заливали розчин поташу об'ємом $40 \mathrm{~cm}^{3}$.

Встановлювали швидкості проходження $6,12,18 \mathrm{~cm}^{3} /$ хв. Після проходження проби крізь шар глини відбирали потрібну кількість розчину для аналізу. Експеримент проводили доти, доки відносний вміст смоли та концентрація мурашиної кислоти в розчині поташу після колонки не досягали такого ж значення, що й у розчині, взятому для очищення.

Одержані графічні залежності динаміки зміни концентрації смолистих речовин у розчинах поташу при різних об'ємних швидкостях їх проходження через адсорбційну колонку зображено на рисунках 2 та 3. 


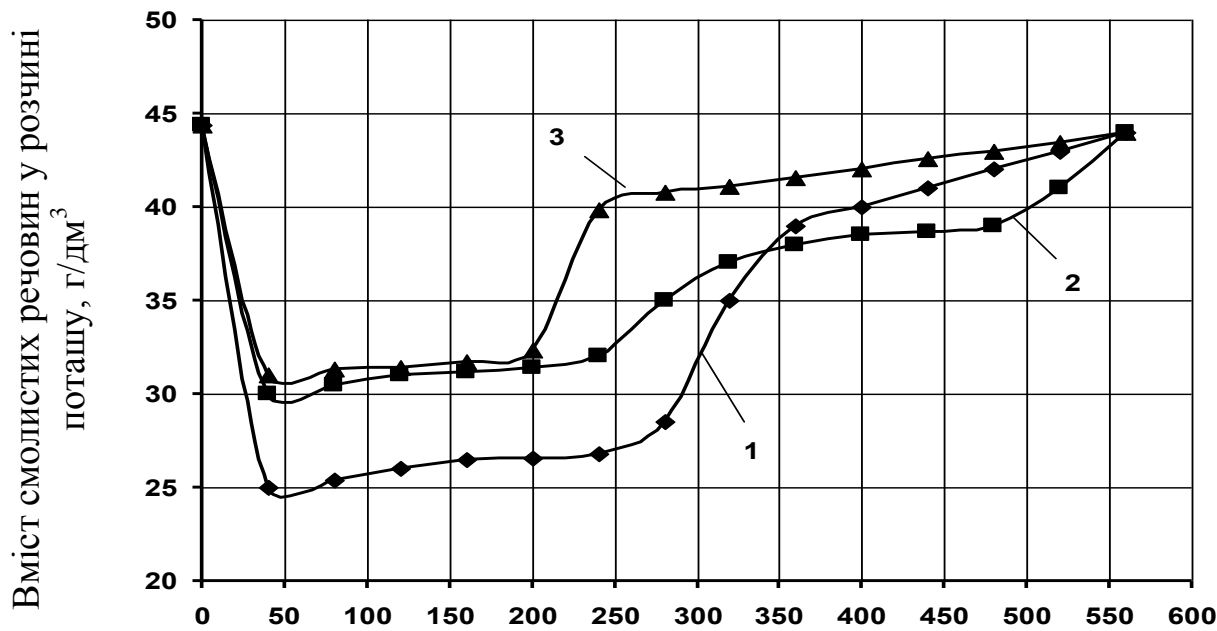

Об'єм розчину поташу, що пройшов очищення, см³

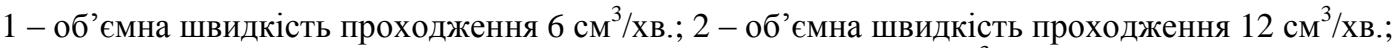
3 - об'ємна швидкість проходження $18 \mathrm{~cm}^{3} / \mathrm{xв}$.

Рисунок 2 - Динаміка зміни концентрації смолистих речовин в розчинах поташу при різних об'ємних швидкостях їх проходження через адсорбційну колонку (III+IV шар бентонітової глини, кислотна активація)

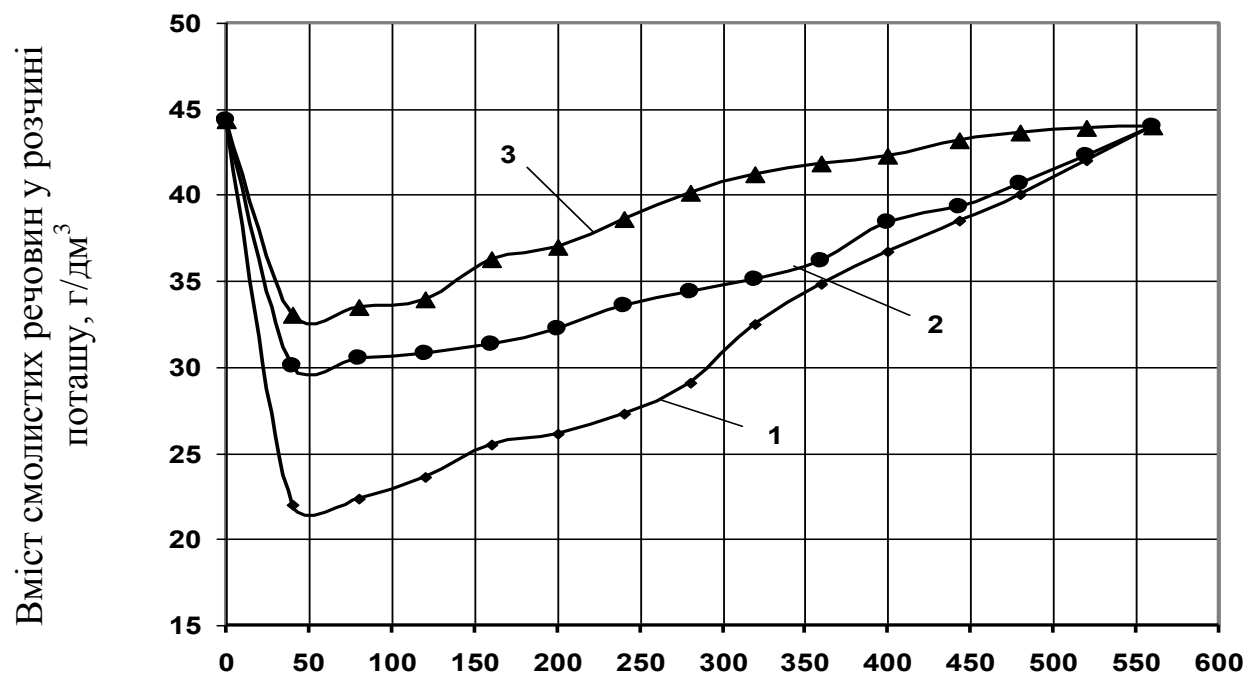

Об'єм розчину поташу, що пройшов очищення, см $^{3}$

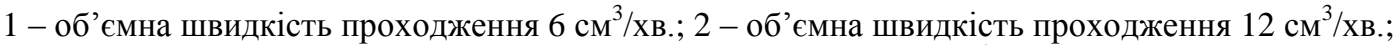
3 - об'ємна швидкість проходження $18 \mathrm{~cm}^{3} / \mathrm{xв}$.

Рисунок 3 - Динаміка зміни концентрації смолистих речовин в розчинах поташу при різних об'смних швидкостях їх проходження через адсорбційну колонку

(II+IV шар бентонітової глини, лужна активація)

Як видно з графічних залежностей (рисунок 2), об'єм розчину поташу, пропущений через адсорбційну колонку, за якого досягається максимальний ступінь очищення від смолистих речовин при всіх швидкостях про- ходження для заданої експериментом кількості активованого адсорбенту, $-40 \mathrm{~cm}^{3}$.

За заданий час поглинається 0,138 г смолистих речовин на 1 г адсорбенту при швидкості проходження $6 \mathrm{~cm}^{3} /$ хв., 0,1 г смо- 
листих речовин на 1 г адсорбенту при швидкості проходження $12 \mathrm{~cm}^{3} /$ хв. та 0,096 г смолистих речовин при швидкості проходження $18 \mathrm{~cm}^{3} /$ хв. Отримані дані свідчать про те, що час контакту адсорбенту з розчином поташу відіграє ключову роль та знижує кількість поглинених смолистих речовин з розчину поташу при збільшенні в 2-3 рази швидкості його пропускання через шар адсорбенту в середньому в 1,7 разу. Тобто з метою забезпечення оптимального часу контакту процес необхідно вести при сталій швидкості пропускання розчину поташу через шар активованої глини $0,036 \mathrm{~m}^{3} /$ год.

В подальшому концентрація смолистих речовин у розчині поташу після очищення плавно зростає до вмісту їх в адсорбенті 0,785 г/г і починає зростати при всіх швидкостях пропускання до настання стану «проскакування», що відповідає теорії фізичної адсорбції. Дослідний час захисної дії адсорбенту при оптимальній швидкості пропускання становить 20 хв. за умови завантаження колонки 140 г активованої глини.

Згідно 3 дослідними даними питома адсорбційна здатність активованої глини становить 0,895 г смолистих речовин на 1 г адсорбенту.

Процес адсорбційного поглинання смолистих речовин бентонітовими глинами II+IV шару, активованими методом лужної активації, зображено на рисунку 3.

Спостерігається подібність динаміки поглинання смолистих речовин із розчинів поташу порівняно з адсорбцією на бентонітовій глині, активованій методом кислотної активації. Максимальний ступінь очищення від смолистих речовин при всіх швидкостях проходження для заданої кількості активованого адсорбенту становить $40 \mathrm{~cm}^{3}$.

За заданий час поглинається 0,16 г смолистих речовин на 1 г адсорбенту при швидкості проходження $6 \mathrm{~cm}^{3} / \mathrm{xв.,} \mathrm{0,1} \mathrm{г} \mathrm{смолистих}$ речовин на $1 \Gamma$ адсорбенту при швидкості проходження $12 \mathrm{~cm}^{3} /$ хв. та 0,08 г смолистих речовин при швидкості проходження $18 \mathrm{~cm}^{3} /$ хв. Отримані дані свідчать про те, що час контакту адсорбенту 3 розчином поташу також відіграє ключову роль та знижує кількість поглинених смолистих речовин з розчину поташу при збільшенні в 2-3 рази швидкості його пропускання через шар адсорбенту в середньому в 1,8 разу. Тобто з метою забезпечення оптимального часу контакту процес не-

(C) А. В. Громико, Г. С. Столяренко, М. В. Позігун, 2020 DOI: $10.24025 / 2306-4412.1 .2020 .189028$ обхідно вести при сталій швидкості пропускання розчину поташу через шар активованої глини $-0,036 \mathrm{~m}^{3} /$ год.

В подальшому концентрація смолистих речовин у розчині поташу після очищення рівномірно зростає. Порівняно з активованою глиною методом кислотної активації при проходженні $240 \mathrm{~cm}^{3}$ розчину поташу через глину, активовану методом лужної активації, кількість поглинених смолистих речовин адсорбентом становить 0,853 г/г. Цей показник для глини лужної активації вищий на 8,7 \% порівняно 3 тим же показником для глини кислотної активації. В подальшому процес адсорбції проходить за більш сталого зниження ступеня очищення до настання стану «проскакування» при тій же кількості пройденого розчину поташу, що пройшов через адсорбційну колонку $-560 \mathrm{~cm}^{3}$. Дослідний час захисної дії адсорбенту при оптимальній швидкості пропускання становить 20 хв. за умови завантаження колонки 140 г активованої глини.

Встановлена дослідним шляхом питома адсорбційна ємність активованої глини становить 0,985 г смолистих речовин на 1 г адсорбенту.

Завданням наступного етапу дослідження було визначення ступеня адсорбції мурашиної кислоти з розчину поташу активованими бентонітовими глинами. Одержані графічні залежності динаміки зміни концентрації мурашиної кислоти в розчинах поташу при різних об'ємних швидкостях їх проходження через адсорбційну колонку зображено на рисунках 4 та 5 .

Згідно 3 отриманими дослідними даними (рисунок 4) оптимальний ступінь очищення від мурашиної кислоти спостерігається при пропусканні через адсорбційну колонку від 40 до $400 \mathrm{~cm}^{3}$ розчину поташу. За цей час формується фронт адсорбції, а максимальний ступінь адсорбції відповідає кількості пропущеного через адсорбент розчину поташу $240 \mathrm{~cm}^{3}$, тобто кількість поглиненої мурашиної кислоти адсорбентом на цей момент становить 0,49 мг/г адсорбенту при швидкості пропускання $6 \mathrm{~cm}^{3} / \mathrm{XB} ., \quad 0,378 \mathrm{мг} / \Gamma$ адсорбенту при швидкості пропускання $12 \mathrm{~cm}^{3} / \mathrm{xв}$. та 0,437 мг/г адсорбенту при швидкості пропускання $18 \mathrm{~cm}^{3} /$ хв. Можна констатувати, що оптимальною швидкістю пропускання розчину поташу через шар активованої глини для заданих умов проведення процесу є $6 \mathrm{~cm}^{3} /$ хв. 


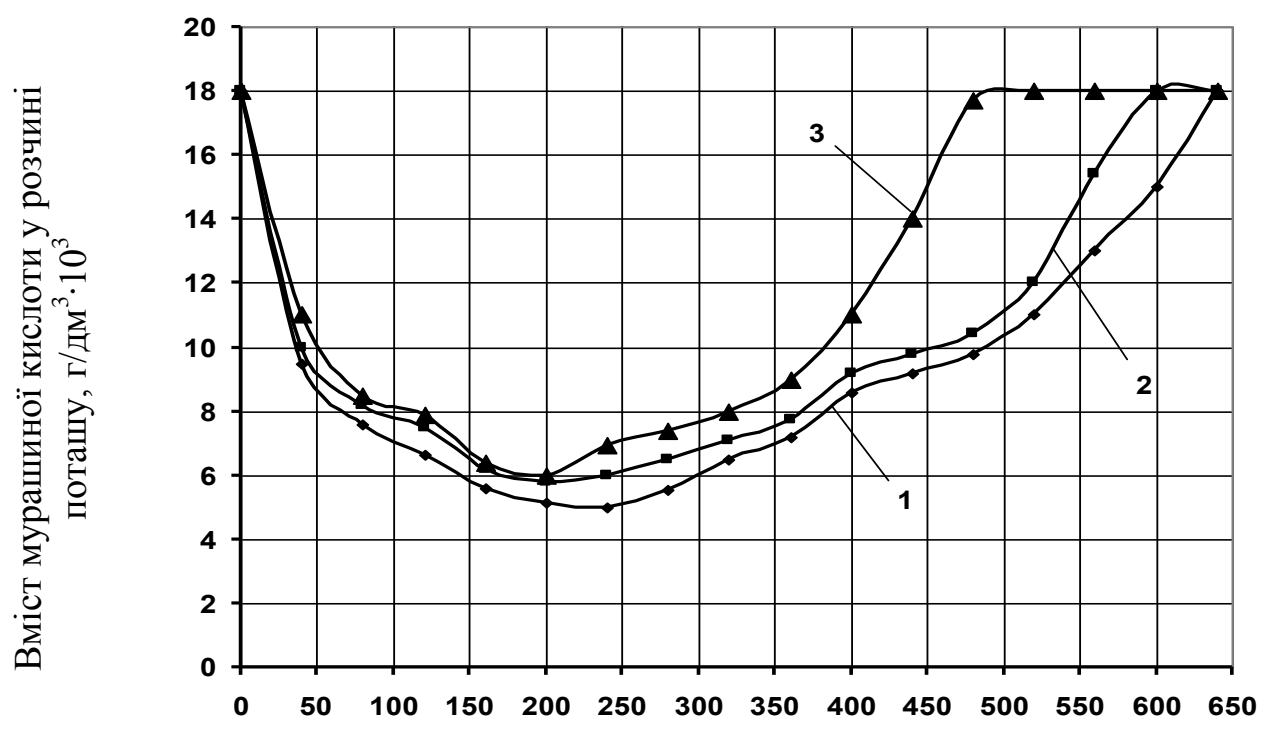

Об'єм розчину поташу, що пройшов очищення, см³

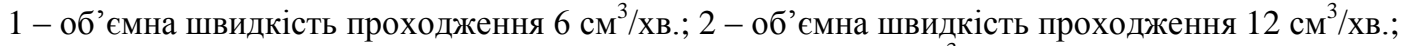
3 - об'ємна швидкість проходження $18 \mathrm{~cm}^{3} /$ хв.

Рисунок 4 - Динаміка зміни концентрації мурашиної кислоти в розчинах поташу при різних об'ємних швидкостях їх проходження через адсорбційну колонку

(III+IV шар бентонітової глини, кислотна активація)

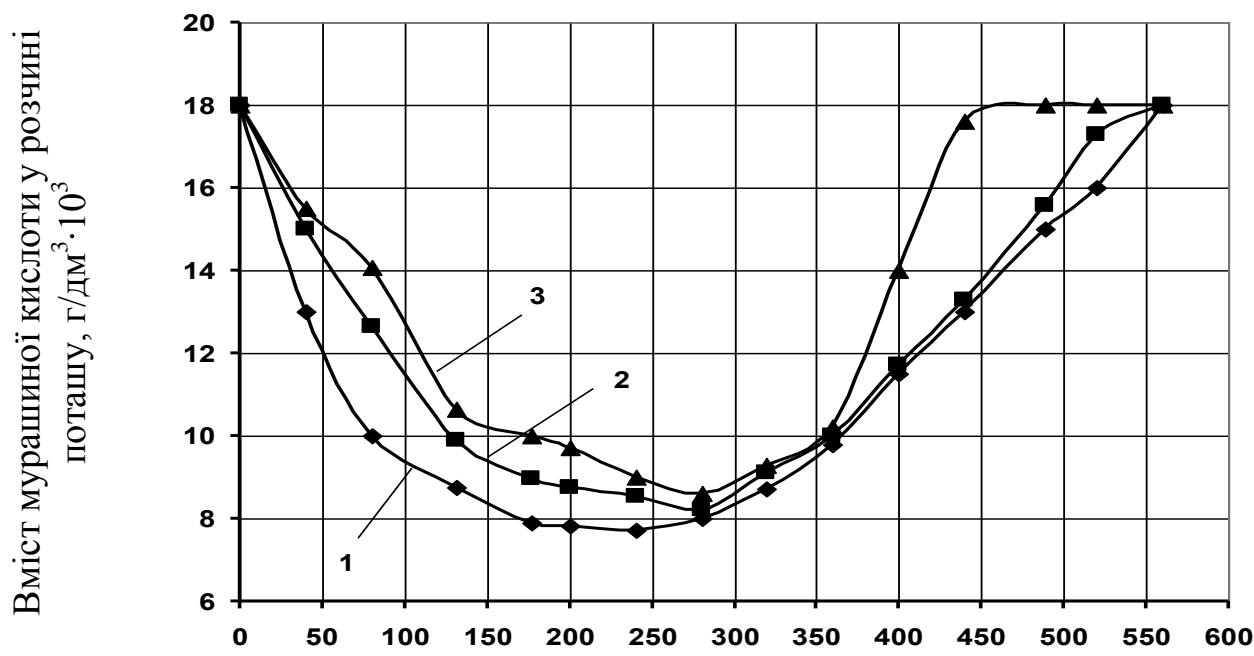

Об'єм розчину поташу, що пройшов очищення, $\mathrm{cm}^{3}$

1 - об’ємна швидкість протікання 6 см³/хв.; 2 - об'ємна швидкість протікання $12 \mathrm{~cm}^{3} /$ хв.; 3 - об'ємна швидкість протікання $18 \mathrm{~cm}^{3} / \mathrm{xв}$.

Рисунок 5 - Динаміка зміни концентрації мурашиної кислоти в розчинах поташу при різних об'ємних швидкостях їх проходження через адсорбційну колонку

(II+IV шар бентонітової глини, лужна активація)

Згідно з отриманими дослідними даними (рисунок 4) оптимальний ступінь очищення від мурашиної кислоти спостерігається при пропусканні через адсорбційну колонку від 40 (C) А. В. Громико, Г. С. Столяренко, М. В. Позігун, 2020 DOI: $10.24025 / 2306-4412.1 .2020 .189028$ до $400 \mathrm{~cm}^{3}$ розчину поташу. За цей час формується фронт адсорбції, а максимальний ступінь адсорбції відповідає кількості пропущеного через адсорбент розчину поташу $240 \mathrm{~cm}^{3}$, 
тобто кількість поглиненої мурашиної кислоти адсорбентом на заданий момент становить 0,49 мг/г адсорбенту при швидкості пропускання $6 \mathrm{~cm}^{3} /$ хв., 0,378 мг/г адсорбенту при швидкості пропускання $12 \mathrm{~cm}^{3} / \mathrm{xв}$. та 0,437 мг/г адсорбенту при швидкості пропускання $18 \mathrm{~cm}^{3} /$ хв. Можна констатувати, що оптимальною швидкістю пропускання розчину поташу через шар активованої глини для заданих умов проведення процесу є $6 \mathrm{~cm}^{3} / \mathrm{xв}$.

Отже дослідний час захисної дії адсорбенту при оптимальній швидкості пропускання становить 67 хв. за умови завантаження колонки 140 г активованої глини.

В подальшому адсорбційна здатність активованої глини швидко знижується, що свідчить про насичення адсорбенту мурашиною кислотою. Так, для швидкості пропускання $6 \mathrm{~cm}^{3} / \mathrm{xв}$. точка «проскакування» досягається при проходженні через адсорбент $640 \mathrm{~cm}^{3}$ розчину поташу, для швидкості пропускання $12 \mathrm{~cm}^{3} /$ хв. точка «проскакування» досягається при проходженні через адсорбент $600 \mathrm{~cm}^{3}$ розчину поташу, а для швидкості пропускання $18 \mathrm{~cm}^{3} /$ хв. точка «проскакування» досягається вже при проходженні через адсорбент $560 \mathrm{~cm}^{3}$ розчину поташу.

Згідно 3 дослідними даними питома адсорбційна ємність активованої глини становить 0,867 мг мурашиної кислоти на 1 г адсорбенту.

Дослідні дані (рисунок 5) свідчать про те, що оптимальний ступінь очищення від мурашиної кислоти на активованій глині спостерігається при пропусканні через адсорбційну колонку від 40 до $440 \mathrm{~cm}^{3}$ розчину поташу. Після формування фронту адсорбції максимальний ступінь адсорбції відповідає кількості пропущеного через адсорбент розчину поташу $240 \mathrm{~cm}^{3}$ при швидкості пропускання $6 \mathrm{~cm}^{3} /$ хв. (кількість поглиненої мурашиної кислоти адсорбентом на цей момент становить 0,378 мг/г адсорбенту) та кількості пропущеного через адсорбент розчину поташу $280 \mathrm{~cm}^{3}$ при швидкості пропускання $12 \mathrm{~cm}^{3} / \mathrm{xв}$. і $18 \mathrm{~cm}^{3} / \mathrm{xв}$. (кількість поглиненої мурашиної кислоти адсорбентом на цей момент становить 0,385 мг/Г та 0,341 мг/г адсорбенту відповідно).

Хоча кількість поглиненої мурашиної кислоти адсорбентом при швидкості пропускання $12 \mathrm{~cm}^{3} /$ хв. більша, ніж при швидкості пропускання $6 \mathrm{~cm}^{3} / \mathrm{xв}$., але ж і об'єм пропущеного розчину поташу також більший. Тобто можна зробити висновок, що оптимальною швидкістю пропускання розчину поташу через шар активованої глини для заданих умов проведення процесу є $6 \mathrm{~cm}^{3} / \mathrm{xв}$.

Отже, дослідний час захисної дії адсорбенту при оптимальній швидкості пропускання становить 20 хв. за умови завантаження колонки 140 г активованої глини.

В подальшому адсорбційна здатність активованої глини швидко знижується, що свідчить про насичення адсорбенту мурашиною кислотою. Так, для швидкості пропускання $6 \mathrm{~cm}^{3} /$ хв. точка «проскакування» досягається при проходженні через адсорбент $560 \mathrm{~cm}^{3}$ розчину поташу, для швидкості пропускання $12 \mathrm{~cm}^{3} / \mathrm{xв}$. точка «проскакування» досягається при проходженні через адсорбент $560 \mathrm{~cm}^{3}$ розчину поташу, а для швидкості пропускання $18 \mathrm{~cm}^{3} / \mathrm{xв}$. точка «проскакування» досягається вже при проходженні через адсорбент $440 \mathrm{~cm}^{3}$ розчину поташу. Останній результат пояснюється недостатнім часом контакту розчину поташу з адсорбентом.

Згідно $з$ дослідними даними питома адсорбційна ємність активованої глини становить 0,689 мг мурашиної кислоти на 1 г адсорбенту.

3 метою пошуку оптимальної кількості адсорбенту в адсорбційну колонку по черзі завантажували глину, що пройшла кислотну або лужну активацію, відповідно 140 г; 190 г; 243 г; 263 г; 1000 г та 1500 г. В кожну $з$ цих колонок наливали розчин поташу об'ємом $500 \mathrm{~cm}^{3}$. Пропускали розчин через адсорбційну колонку і визначали ступінь очищення від смолистих сполук.

Результати досліджень зображено у вигляді графічної залежності на рисунку 6 .

Згідно $з$ отриманими дослідними даними до величини співвідношення розчин поташу: адсорбент 1:1,9 спостерігається значне зниження вмісту смол в очищеному розчині поташу, де відзначається значне зростання ступеня очищення. Подальша зміна цього співвідношення до 3:1 дає найбільше зниження вмісту смол в очищеному розчині поташу. Але це більш ніж у 6 разів збільшує кількість адсорбенту в процесі очищення, що може призвести до збільшення собівартості очисного процесу. Тобто оптимальним співвідношенням розчин поташу : адсорбент можна вважати 1:2. 


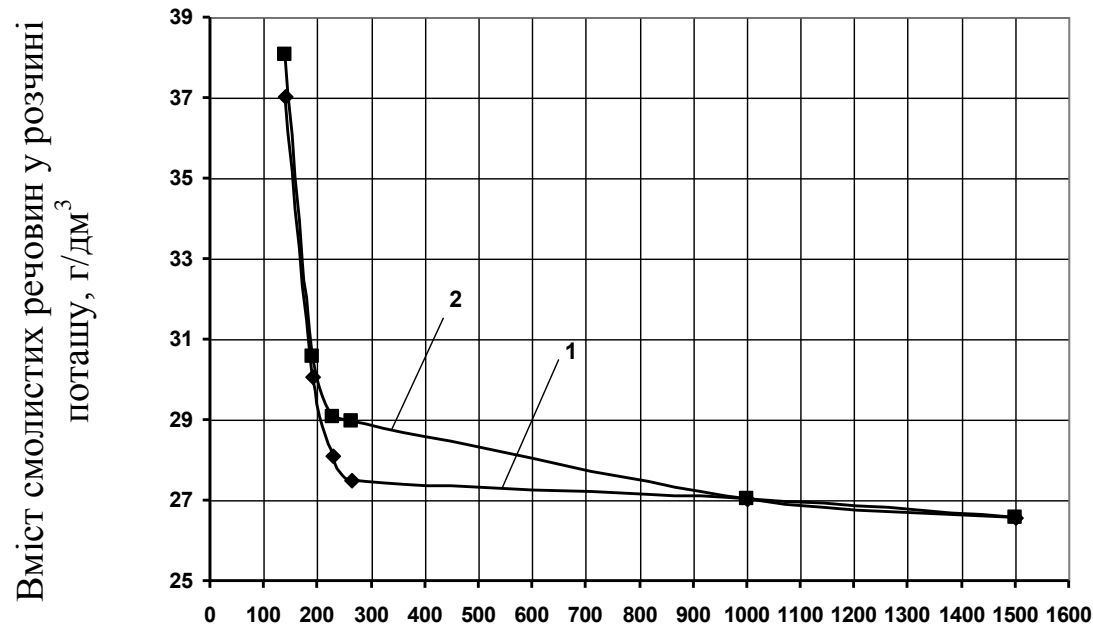

Кількість адсорбенту, г

1 - глина III+IV шару, кислотна активація; 2 - глина II+IV шару, лужна активація

Рисунок 6 - Динаміка зміни концентрації смолистих речовин у розчинах поташу при різній кількості адсорбенту

Під час очищення на активованих глинах розчинів поташу було також перевірено ступінь поглинання таких сполук із розчинів поташу, як $\mathrm{K}_{2} \mathrm{CO}_{3}, \mathrm{KHCO}_{3}$, діетаноламін (ДЕА) та $\mathrm{V}_{2} \mathrm{O}_{5}$ різними видами сорбентів.

Дані досліджень зведено в таблицю 1.

Таблиця 1 - Результати очищення розчину поташу на активованих глинах

\begin{tabular}{|c|c|c|c|c|c|}
\hline № & Адсорбент & $\begin{array}{c}\text { Аналізована } \\
\text { речовина }\end{array}$ & $\begin{array}{c}\text { Вихідна } \\
\text { концент- } \\
\text { рація, \% }\end{array}$ & $\begin{array}{c}\text { Концентрація } \\
\text { в очищеному } \\
\text { розчині, \% }\end{array}$ & $\begin{array}{c}\text { Ступінь } \\
\text { поглинання, } \\
\%\end{array}$ \\
\hline \multirow{4}{*}{1} & \multirow{4}{*}{ II+IV шар, лужна активація } & $\mathrm{K}_{2} \mathrm{CO}_{3}$ & 17.12 & 16.72 & 2.33 \\
\hline & & $\mathrm{KHCO}_{3}$ & 17.26 & 17.03 & 1.33 \\
\hline & & ДЕА & 2.414 & 2.182 & 9.61 \\
\hline & & $\mathrm{V}_{2} \mathrm{O}_{5}$ & 0.4486 & 0.4485 & 0.022 \\
\hline \multirow{4}{*}{2} & \multirow{4}{*}{$\begin{array}{c}\text { III+IV шар, кислотна } \\
\text { активація }\end{array}$} & $\mathrm{K}_{2} \mathrm{CO}_{3}$ & 17.12 & 17.01 & 0.64 \\
\hline & & $\mathrm{KHCO}_{3}$ & 17.26 & 17.08 & 1.04 \\
\hline & & ДЕА & 2.414 & 2.196 & 9.03 \\
\hline & & $\mathrm{V}_{2} \mathrm{O}_{5}$ & 0.4486 & 0.4484 & 0.044 \\
\hline \multirow{4}{*}{3} & \multirow{4}{*}{ Активоване вугілля } & $\mathrm{K}_{2} \mathrm{CO}_{3}$ & 17.12 & 16.34 & 4.55 \\
\hline & & $\mathrm{KHCO}_{3}$ & 17.26 & 17.02 & 1.39 \\
\hline & & ДЕА & 2.414 & 2.108 & 12.68 \\
\hline & & $\mathrm{V}_{2} \mathrm{O}_{5}$ & 0.4486 & 0.4479 & 0.15 \\
\hline
\end{tabular}

Як видно 3 отриманих даних, найнижчим ступенем поглинання цільових компонентів розчину поташу є глина кислотної активації. Глина лужної активації також поглинає в процесі адсорбції $\mathrm{K}_{2} \mathrm{CO}_{3}, \mathrm{KHCO}_{3}$, ДЕА та $\mathrm{V}_{2} \mathrm{O}_{5}$, але меншою мірою, ніж глина кислотної активації.

Найбільший ступінь поглинання має активоване вугілля. Цей недолік активованого вугілля викликає необхідність постійного поповнення поглинального розчину новими порціями $\mathrm{K}_{2} \mathrm{CO}_{3}, \mathrm{KHCO}_{3}$, ДЕА.
Висновки. В ході проведених експериментальних досліджень по очищенню розчинів поташу від смолистих сполук та мурашиної кислоти на активованих бентонітових глинах методом кислотної активації отримано наступні експериментальні дані:

- процес очищення необхідно вести при сталій швидкості пропускання розчину поташу через шар активованої глини $0,036 \mathrm{~m}^{3} /$ год.;

- визначено адсорбційну здатність активованої глини при максимальному ступені

(C) А. В. Громико, Г. С. Столяренко, М. В. Позігун, 2020 DOI: $10.24025 / 2306-4412.1 .2020 .189028$ 
очищення, який становить 0,785 г смолистих речовин на 1 г адсорбенту та 0,49 мг мурашиної кислоти на 1 г адсорбенту;

- визначено експериментальний час захисної дії адсорбенту, який становить 2 год. для 1 кг адсорбенту.

Очищення розчинів поташу від смолистих сполук та мурашиної кислоти на активованих бентонітових глинах методом лужної активації дало наступні результати:

- з'ясовано, що процес очищення необхідно вести при сталій швидкості пропускання розчину поташу через шар активованої глини $-0,036 \mathrm{~m}^{3} /$ год.;

- визначено адсорбційну здатність активованої глини при максимальному ступені очищення, який становить 0,853 г смолистих речовин на 1 г адсорбенту та 0,378 мг мурашиної кислоти на 1 г адсорбенту;

- визначено експериментальний час захисної дії адсорбенту, який становить 2 год. для 1 кг адсорбенту.

Експериментально визначено, що оптимальним співвідношенням матеріальних потоків розчин поташу : адсорбент є 1:2.

Виявлено, що найнижчим ступенем поглинання цільових компонентів розчину поташу є глина кислотної активації. Глина лужної активації також поглинає в процесі адсорбції $\mathrm{K}_{2} \mathrm{CO}_{3}, \mathrm{KHCO}_{3}$, ДЕА та $\mathrm{V}_{2} \mathrm{O}_{5}$, але більшою мірою, ніж глина кислотної активації. Активоване вугілля володіє найбільшим ступенем поглинання щодо таких компонентів розчину поташу, як $\mathrm{K}_{2} \mathrm{CO}_{3}, \mathrm{KHCO}_{3}$, ДЕА, що за рахунок необхідності їх поновлення підвищує виробничі витрати на очищення синтез-газу від оксиду вуглецю (IV).

\section{Список використаних джерел}

[1] Аммиак. Вопросы технологии / под ред. Н. А. Янковского. Донецк: Новая печать, 2001.

[2] Н. Ю. Щукин, и Н. П. Матросов. "Новые абсорбенты в очистке от $\mathrm{CO}_{2} "$, Химическая промышленность, № 9, с. 32-52, 2005.

[3] А. В. Степанов, Получение водорода $u$ водородсодержащих газов. Киев: Наук. думка, 1982.

[4] Е. И. Еремин, Основы химической термодинамики. Москва: Высшая школа, 1974.

[5] Е. Я. Мельников, Справочник азотчика: Физико-химические свойства газов и жидкостей. Производство технологических газов. Очистка технологических га-

(C) А. В. Громико, Г. С. Столяренко, М. В. Позігун, 2020 DOI: $10.24025 / 2306-4412.1 .2020 .189028$ зов. Синтез аммиака. Москва: Химия, 1986.

[6] Ж.-Л. Пейтави, С. Капдевиль, и Э. Лакамуар, "Регенеративный способ раскисления газа, содержащего $\mathrm{CO}_{2}$, a также жидкие углеводороды, с помощью жидкого абсорбента на основе активированного метилдиэтаноламина", Пат. РФ № 2201282 / патентообладатель Елф Эксплорасьон Продюксьон; заявл. 20.04.1999; опубл. 27.03.2003.

[7] Т. А. Михайлова, Н. Т. Никущенко, $\begin{array}{ll}\text { M. И. Нагродский, } & \text { В. В Потехин, и }\end{array}$ С. А. Луговской, "Способ получения метилдиэтаноламина", Пат. РФ № 2380354 / патентообладатель ЗАО «Химтэк Инжиниринг»; заявл. 06.05.2008; опубл. 27.01.2010.

[8] "Способ очистки газов в производстве аммиака", А.c. СCCP № 739006, кл. С 02 F 1/46, Бюллетень изобретений, № 40, 1976.

[9] А. К. Бабченко и др., "Установка для производства аммиака", Пат. РФ

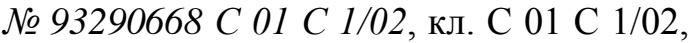
1994.

[10] Є. В. Мислюк, Н. В. Іванова, В. М. Сорич, А. В. Громико, та Г. С. Столяренко, "Спосіб регенерації розчинів поташу “Карсол” і “Бенфілд”", Пат. Украӥни № 65306, заявл. 10.03.2003; опубл. 15.03.2004.

\section{References}

[1] Ammonia. Technology issues, N. A. Yankovsky, ed. Donetsk: Novaya pechat, 2001 [in Russian].

[2] N. Y. Shchukin, and N. P. Matrosov, "New absorbents in $\mathrm{CO}_{2}$ purification", Himicheskaya promyshlennost, no. 9, pp. 32-52, 2005 [in Russian].

[3] A. V. Stepanov, Production of hydrogen and hydrogen-containing gases. Kiev: Nauk. dumka, 1982 [in Russian].

[4] E. I. Eremin. Fundamentals of chemical thermodynamics. Moscow: Vysshaya shkola, 1974 [in Russian].

[5] E. Ya. Melnikov, Nitrogen reference book: Physico-chemical properties of gases and liquids. Production of process gases. Purification of process gases. Ammonia synthesis. Moscow: Himiya, 1986 [in Russian].

[6] J.-L. Peitavi, S. Capdeville, and E. Lakamuar, "Regenerative method of 
deoxidation of $\mathrm{CO}_{2}$-containing gas, as well as liquid hydrocarbons, using liquid absorbent based on activated methyldiethanolamine", Pat. RF no. 2201282 / patent holder Elf Explosion Producer; stated 04/20/1999; publ. 27.03.2003 [in Russian].

[7] T. A. Mikhailova, N. T. Nikushchenko, M. I. Nagrodsky, V. V. Potekhin, and S. A. Lugovskaya, "The method of obtaining methyldiethanolamine", Pat. RF no. 2380354 / patent holder Khimtek Engineering; stated 06.05.2008; publ. 27.01.2010 [in Russian].
[8] "Method for gas purification in ammonia production", USSR copyright certificate no. 739006 , cl. C $02 \mathrm{~F} \mathrm{1/46, \text {Byulleten }}$ izobretenij, no. 40, 1976 [in Russian].

[9] A. K. Babchenko et al., "Installation for ammonia production", Pat. $R F$ no. 93290668 C 01 C 1/02, cl. C 01 C 1/02, 1994 [in Russian].

[10] E. V. Mislyuk, N. V. Ivanova, V. M. Sorych, A. V. Gromiko, and H. S. Stolyarenko, "Method of regeneration of potassium solutions "Carsol" and "Benfield"", Pat. Ukraine no. 65306, stated 10.03.2003; publ. $03 / 15 / 2004$ [in Ukrainian].

A. V. Gromyko, Ph. D., associate professor, e-mail: gromyko-andru@ukr.net,

H. S. Stolyarenko, D.Tech.Sc., professor,

M. V. Pozigun, student

e-mail: lemax_95@ukr.net

Cherkasy State Technological University

Shevchenko blvd, 460, Cherkasy,18006, Ukraine

\section{USE OF NATURAL SORBENTS IN THE PROCESSES OF PURIFICATION OF ABSORBING POTASSIUM SOLUTIONS OF AMMONIA PRODUCTION}

Today, the problem of purification of monoethanolamine (MEA) solutions and potassium-based, deethanolamine (DEA) activated solutions to purify gases from carbon dioxide is very acute at the enterprises of chemical industry for the production of ammonia in the synthesis scheme, at the stage of carbon monoxide conversion.

Long-term use of such solutions (Carsol solution (25-28\% of $\mathrm{KHCO}_{3}$ and 1,.8\% of diethanolamine) and Benfield solution (29-30\% of $\mathrm{KHCO}_{3}$ and 2,9\% of diethanolamine)) leads to a decrease in their absorption capacity. At the stage of high-temperature regeneration, indirect processes of thermal diethanolamine decomposition occur in the volume of solutions, resulting in the formation of resinous substances and corrosion-active compounds, for removal of which additional stage for filtration of solutions on carbon filters is introduced into the flow chart.

Experimental studies have been conducted at the Department of Chemical Technology and Water Purification to determine the adsorption capacity of activated bentonite clays for absorption of solutions of resinous substances and corrosion-active compounds. During the work, it has been established that bentonite clays activated by acid and alkaline activation have sufficient absorption capacity for resinous substances and corrosion-active compounds to replace the activated carbon used for these production purposes.

It is revealed that the clay of acid activation is characterized by the lowest degree of absorption of the target components of the potassium solution. The clay of alkaline activation also absorbs $\mathrm{K}_{2} \mathrm{CO}_{3}, \mathrm{KHCO}_{3}$, diethanolamine and $\mathrm{V}_{2} \mathrm{O}_{5}$ in the process of adsorption but to a greater extent than the clay of acid activation. Activated carbon has the highest degree of absorption. Activated carbon has the highest degree of absorption. This disadvantage of activated carbon necessitates the constant replenishment of the absorbent solution with new portions of $\mathrm{K}_{2} \mathrm{CO}_{3}, \mathrm{KHCO}_{3}$, diethanolamine, which increases the production costs for purification of synthesis gas from carbon monoxide (IV).

Keywords: ammonia production, potash solutions, purification, adsorption, activated clay, corrosion.

Стаття надійшла 23.12.2019

Прийнято 21.01.2020

(C) А. В. Громико, Г. С. Столяренко, М. В. Позігун, 2020 DOI: 10.24025/2306-4412.1.2020.189028 